Article

\title{
Proteomic Analysis of Human Serum from Patients with Chronic Kidney Disease
}

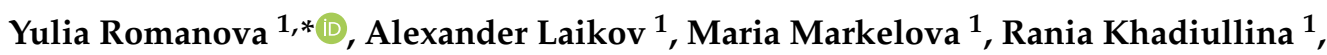 \\ Alfiz Makseev ${ }^{2}$, Milausha Hasanova ${ }^{2,3}$, Albert Rizvanov ${ }^{1} \mathbb{D}$, Svetlana Khaiboullina ${ }^{4}$ and \\ Ilnur Salafutdinov ${ }^{1, *}$ \\ 1 Institute of Fundamental Medicine and Biology, Kazan Federal University, 420008 Kazan, Tartastan, Russia; \\ alexander.laikov@yandex.ru (A.L.); mimarkelova@gmail.com (M.M.); nazyrova.95@yandex.ru (R.K.); \\ rizvanov@gmail.com (A.R.) \\ 2 Republican Clinical Hospital Ministry of Health Republic of Tatarstan, 420064 Kazan, Tatarstan, Russia; \\ alfiz.mar82@inbox.ru (A.M.); milyash@inbox.ru (M.H.) \\ 3 Department of Urology and Nephrology, Kazan State Medical Academy, 420012 Kazan, Tatarstan, Russia \\ 4 Department of Microbiology and Immunology, University of Nevada, Reno, NV 89557, USA; \\ sv.khaiboullina@gmail.com \\ * Correspondence: magnolina@list.ru (Y.R.); sal.ilnur@gmail.com (I.S.); Tel.: +7-927-418-90-02 (Y.R.); \\ $+7-917-867-43-60$ (I.S.)
}

Received: 21 January 2020; Accepted: 5 February 2020; Published: 7 February 2020

\begin{abstract}
Chronic kidney disease (CKD) is an important public health problem in the world. The aim of our research was to identify novel potential serum biomarkers of renal injury. ELISA assay showed that cytokines and chemokines IL-1 $\beta$, IL-2, IL-4, IL-5, IL-6, IL-7, IL-8, IL-9, IL-10, IL-12 (p70), IL-13, IL-15, IL-17, Eotaxin, FGFb, G-CSF, GM-CSF, IP-10, MCP-1, MIP- $1 \alpha$, MIP-1 $\beta$, PDGF-1bb, RANTES, TNF- $\alpha$ and VEGF were significantly higher $(\mathrm{R}>0.6, p$ value $<0.05)$ in the serum of patients with CKD compared to healthy subjects, and they were positively correlated with well-established markers (urea and creatinine). The multiple reaction monitoring (MRM) quantification method revealed that levels of HSP90B2, AAT, IGSF22, CUL5, PKCE, APOA4, APOE, APOA1, CCDC171, CCDC43, VIL1, Antigen KI-67, NKRF, APPBP2, CAPRI and most complement system proteins were increased in serum of CKD patients compared to the healthy group. Among complement system proteins, the C8G subunit was significantly decreased three-fold in patients with CKD. However, only AAT and HSP90B2 were positively correlated with well-established markers and, therefore, could be proposed as potential biomarkers for CKD.
\end{abstract}

Keywords: chronic kidney disease; inflammation; cytokines; biomarkers; 2D-DIGE; multiple reaction monitoring

\section{Introduction}

Chronic kidney disease (CKD) is defined by a gradual loss of kidney function for more than three months. CKD remains an increasing public health threat affecting up to $16 \%$ of the global population [1]. According to the 2016 Global Burden of Disease study, CKD caused 16.9 deaths per 100,000 in 2016 [2]. CKD is characterized by progressive kidney damage due to renal circulatory impairment, which is common for patients diagnosed with diabetes and hypertension. The treatment is not specific and aimed to improve the underlying condition as well as to manage complications.

The initial symptoms of CKD are not specific, which prevents early diagnosis. Diagnosis of CKD is based on the calculation of glomerular filtration rate (GFR), detection of albuminuria and a kidney biopsy $[3,4]$. These diagnostic methods are often used at the late stage of disease, when kidney 
damage is advanced and often irreversible. Therefore, identification of biomarkers for early diagnosis of CKD is important. Several markers of kidney inflammation were proposed for CKD diagnosis including plasma and urine interleukins and chemokines (IL-18, IL-10, IL-6, MCP-1, FGF-23) [5,6]. Also, to improve predicting CKD prognosis, the biomarkers of renal tubular injury NGAL, KIM-1, TIMP-2 and IGFBP-7 have been shown to be especially promising $[7,8]$. Development of novel genetic tests and identification of genomic biomarkers can also improve the management of CKD by facilitating early diagnosis and advancing patient management $[9,10]$. Nevertheless, investigation of novel and effective biomarkers for early CKD diagnosis remains an important aim.

Changes in blood proteins are commonly monitored to diagnose the disease, mainly because of their easy access. Also, changes in blood components can be detected in the early stage of the disease. This is especially true in CKD, where changes in kidney filtration result in significant alterations in blood chemistry. For example, increased serum creatinine and urea levels, electrolyte imbalance and increased blood coagulation are found in CKD patients. Therefore, we suggest that potential CKD biomarkers might be identified in patient serum.

Previous studies of novel, early-stage CKD biomarkers have used different proteomic approaches [11-14]. We applied a two-dimensional fluorescence difference gel electrophoresis (2D-DIGE) approach to separate depleted serum proteins in CKD and control serum. High-abundance proteins were deleted to improve visualization of protein spots. After differentially expressed proteins were identified, these proteins were quantified with multiple reaction monitoring (MRM) in the serum samples of patients $(n=26)$ and control groups $(n=10)$.

\section{Materials and Methods}

\subsection{Subjects}

Serum samples from 26 adult patients with terminal stage CKD (18 male and 8 female; age $53.0 \pm 16.2 \mathrm{y}$ ) and 10 control healthy subjects older than $18 \mathrm{y}$ ( 4 male and 6 female; age $29 \pm 6.7 \mathrm{y}$ ) were used in this study. CKD patients not treated with hemodialysis were recruited from the Department of Nephrology, Republican Clinical Hospital Ministry of Health Republic of Tatarstan. The diagnosis of CKD was confirmed by clinical tests (eGFR $<15 \mathrm{~mL} / \mathrm{min} / 1.73 \mathrm{~m}^{2}$, protein in urea $>0.033 \mathrm{~g} / \mathrm{L}$, serum creatinine $>115 \mathrm{mmol} / \mathrm{L}$, etc.). Baseline clinical characteristics and laboratory data of the study population are summarized in Table 1 . Serum samples were stored at $-80^{\circ} \mathrm{C}$ until they were used.

\subsection{Ethics Statement}

The Ethics Committee of the Kazan Federal University approved this study (protocol N4/09), and informed written consent was obtained from each patient and control according to the Guidelines approved under this Protocol (article 20, Federal Law "Protection of Health Right of Citizens of Russian Federation" N323- FZ, 11.21.2011).

\subsection{D-DIGE of Serum Proteins after Depletion}

Unspecific depletion of high-abundance proteins in serum samples $(200 \mu \mathrm{L})$ was done using a commercially available kit, ProteoMiner (Bio-Rad, Hercules, CA, USA), according to the manufacturer's instructions with a minor modification. Briefly, $200 \mu \mathrm{L}$ of serum was loaded into the prepared spin column with protein-binding sorbent, incubated for $2 \mathrm{~h}$ at room temperature, and then washed with PBS (150 mM NaCl, $10 \mathrm{mM} \mathrm{NaH2PO} 4 \mathrm{pH} 7.4)$ and water. Finally, the protein was eluted using a denaturing buffer (8 Murea, 10 mMTris-HCl, pH8.5, 3\% CHAPS (3-[(3-Cholamidopropyl)dimethylammonio]-1-propanesulfonate hydrate), 2\% NP40 (nonylphenol ethoxylate)) and used for 2D-DIGE. 
Table 1. Characteristics of the study population.

\begin{tabular}{|c|c|}
\hline Parameters * & CKD Patients \\
\hline Age (y) & $53.0 \pm 16.2$ \\
\hline Sex (males/females) & $18 / 8$ \\
\hline $\mathrm{eGFR}\left(\mathrm{mL} / \mathrm{min} / 1.73 \mathrm{~m}^{2}\right)$ & $14.7 \pm 3.1$ \\
\hline Diagnosis of CKD (number of patients) & 26 \\
\hline Chronic glomerulonephritis & 18 \\
\hline Diabetes & 3 \\
\hline Chronic gouty nephropathy & 2 \\
\hline Others or unknown & 3 \\
\hline Body mass index $\left(\mathrm{kg} / \mathrm{m}^{2}\right)$ & $25.8 \pm 5.6$ \\
\hline Systolic blood pressure $(\mathrm{mmHg})$ & $128.7 \pm 23.2$ \\
\hline Diastolic blood pressure (mmHg) & $79.2 \pm 18.3$ \\
\hline Creatinine $(\mathrm{mg} / \mathrm{dL})$ & $7.25 \pm 3.8$ \\
\hline Urea $(\mathrm{mg} / \mathrm{dL})$ & $135.0 \pm 70.2$ \\
\hline Albumin $(\mathrm{g} / \mathrm{dL})$ & $3.8 \pm 0.5$ \\
\hline Total cholesterol (mg/dL) & $177.8 \pm 40.2$ \\
\hline HDL cholesterol (mg/dL) & $52.1 \pm 28.4$ \\
\hline LDL cholesterol (mg/dL) & $110.6 \pm 45.6$ \\
\hline Triglyceride (mg/dL) & $141.9 \pm 50.1$ \\
\hline
\end{tabular}

* Abbreviations: CKD—chronic kidney disease; eGFR—estimated glomerular filtration rate; HDL—high-density lipoprotein; LDL-low-density lipoprotein.

Serum proteins were separated using 2D-DIGE as previously described [15]. Isoelectric focusing (IEF) was done with commercially available $17 \mathrm{~cm}$ IPG (immobilized $\mathrm{pH}$ gradient) strips in the $\mathrm{pH}$ range 3-10 (Bio-Rad, Hercules, CA, USA) according to the manufacturer's instructions. We used $150 \mu \mathrm{g}$ of each protein sample to label with $0.4 \mathrm{mM}$ cyanine dyes Cy3 or Cy5 (Lumiprobe, Moscow, Russia) before IEF. The samples were mixed, diluted in the rehydration buffer (8 Murea, $10 \mathrm{mMTris}-\mathrm{HCl}(\mathrm{pH} 8.5)$, $3 \%$ CHAPS, 2\% NP40, 50 mM DTT (dithiothreitol), 0.4\% Pharmalyte, $\mathrm{pH}$ range 3-10 (GE Healthcare, Chicago, IL, USA)) and loaded into the strip for active rehydration for $12 \mathrm{~h}$. Isoelectric focusing was carried out using the Protean 12 IEF cell (Bio-Rad, Hercules, CA, USA). After IEF, the strips were incubated for $10 \mathrm{~min}$ in the equilibration buffer ( $6 \mathrm{M}$ urea, $0.375 \mathrm{M}$ Tris- $\mathrm{HCl}, \mathrm{pH} 8.8,2 \%$ SDS (sodium dodecyl sulfate)), containing $2 \%$ DTT, and for $10 \mathrm{~min}$ in the same equilibration buffer, containing $2.5 \%$ iodoacetamide. Second-dimension electrophoresis was performed on self-cast gradient $9 \%-16 \%$ polyacrylamide gels. Gels were scanned with $100 \mu \mathrm{m}$ pixel resolution using the Typhoon FLA 9500 scanner (GE Healthcare, Chicago, IL, USA). Then, the gels were stained with silver nitrate [16].

\subsection{Protein Identification}

Collected protein spots were destained using ferricyanide-thiosulfate as previously described [17] with some modifications. Briefly, gel pieces were washed with Milli-Q water and destained using a 30 $\mathrm{mM}$ potassium ferricyanide and $100 \mathrm{mM}$ sodium thiosulfate solution for $5 \mathrm{~min}$. Then, the gel pieces were rinsed three times with Milli-Q water, dehydrated using acetonitrile, and digested overnight $\left(0.1 \%\right.$ trypsin (MS grad, Promega, Madison, WI, USA) at $37^{\circ} \mathrm{C}$ ). Peptides were extracted using $0.2 \%$ trifluoroacetic acid (TFA) followed by incubation in $100 \%$ acetonitrile (ACN) for $30 \mathrm{~min}$. Collected peptides were dried at $45^{\circ} \mathrm{C}$ for $2 \mathrm{~h}$, dissolved in $5 \mu \mathrm{L}$ of $0.2 \%$ TFA and analyzed by a MALDI-TOF mass spectrometer Ultraflex (Bruker Daltonics GmbH, Bremen, Germany). The spectra were recorded in positive reflector mode from 700 to $3500 \mathrm{~m} / \mathrm{z}$. Peptide mass fingerprinting (PMF) was performed using the MASCOT software for searching matches in Swiss-Prot and NCBI databases.

\subsection{Preparation of Serum Tryptic Digests}

Tryptic digestion was carried out manually as previously described [18] with some modifications. Serum $(8 \mu \mathrm{L})$ was diluted in $196.5 \mu \mathrm{L}$ of $25 \mathrm{mM}$ ammonium bicarbonate before protein denature 
by adding $30 \mu \mathrm{L}$ of $10 \%$ sodium deoxycholate. Then, samples were reduced $(26.1 \mu \mathrm{L}$ of $50 \mathrm{mM}$ tris(2-carboxyethyl)phosphine (TCEP) at $60{ }^{\circ} \mathrm{C}$ for $30 \mathrm{~min}$ ) and alkylated $(29.0 \mu \mathrm{L}$ of $100 \mathrm{mM}$ iodoacetamide; at $37{ }^{\circ} \mathrm{C}$ for $30 \mathrm{~min}$ in the dark). The remaining iodoacetamide was quenched by adding $29.0 \mu \mathrm{L}$ of $100 \mathrm{mM}$ DTT ( $37^{\circ} \mathrm{C} ; 30 \mathrm{~min}$ ). Each sample was digested with $4 \mu \mathrm{L}$ of $0.1 \%$ trypsin (MS grad, Promega, Madison, WI, USA) at $37^{\circ} \mathrm{C}$ for $16 \mathrm{~h}$. Digestion was quenched using formic acid at a final concentration $0.5 \% \mathrm{v} / \mathrm{v}$. Samples were centrifuged $(10 \mathrm{~min}$ at $10000 \times g)$, and supernatants were desalted and concentrated using solid phase extraction (Discovery DSC-18 (50 mg) cartridges (Supelco, Bellefonte, PA, USA)) according to the manufacturer's protocol. Eluted peptides were dried at $45{ }^{\circ} \mathrm{C}$ for several hours and rehydrated $(40 \mu \mathrm{L}$ of $0.1 \% v / v$ formic acid in water/acetonitrile (95/5)) prior to LC-MRM/MS analysis.

\subsection{LC-MRM/MS Analysis of Serum Digests}

Peptides $(10 \mu \mathrm{L})$ were separated in a reversed phase analytical column $(100 \times 2.1 \mathrm{~mm}$ i.d., Titan C18, $1.9 \mu \mathrm{m}$ particle size (Supelco, Bellefonte, PA, USA)) with an Agilent 1290 Infinity UHPLC system coupled to a QTRAP 6500 (AB Sciex, Darmstadt, Germany) mass spectrometer. Proteins were separated using $400 \mu \mathrm{L} / \mathrm{min}$ flow rate and a gradient from $5 \%-95 \%$ mobile phase $\mathrm{B}$, temperature $40{ }^{\circ} \mathrm{C}$ and a $25 \mathrm{~min}$ total run time. Mobile phase A consisted of $95 \% 0.1 \% v / v$ formic acid in water and $5 \% \mathrm{ACN}$, and mobile phase B consisted of $95 \% \mathrm{ACN}$ and $5 \% 0.1 \%$ formic acid in water. The linear gradients were as follows (time: \% B): $0.3 \mathrm{~min}$ : 5\% B; $17 \mathrm{~min}: 40 \% \mathrm{~B} ; 18 \mathrm{~min}: 95 \% \mathrm{~B} ; 21.5 \mathrm{~min}$ : 95\% B; 23 min: 5\% B; 25 min: 95\% B. All acquisition methods used the following parameters: $5200 \mathrm{~V}$ capillary voltage; source type Turbo Spray Ion Drive with temperature $500{ }^{\circ} \mathrm{C}$; curtain gas 35 psi; declustering potential $51 \mathrm{~V}$; collision energy was automatically optimized for each transition; flow rate $0.4 \mathrm{~mL} / \mathrm{min}$. Mass spectrometric data were analyzed using MultiQuant 3.0.2 software (AB Sciex, Darmstadt, Germany).

Skyline 3.6.0 [19] was used to generate precursor/fragment ion pairs, so-called MRM transitions, in silico [20]. The following options were selected: the peptide length was set to 8-25 amino acids, no post-translational modification (PTM) and one missed cleavage was allowed. In addition, two or three charge states of peptides were chosen for further MRM experiments. At least two peptides were chosen for identification of the target protein (Supplementary Table S1). The MRM method included at least three MRM transitions per peptide to select the best transition. Data analysis was done, and the areas for all the transitions were calculated using the Analyst 1.6.2 and MultiQuant 3.0.2 software (AB Sciex, Darmstadt, Germany). Used peptides with unique sequences and scheduled MRM transitions are given in Table 2.

\subsection{Analysis of Serum Levels of Cytokines}

Quantitative analyses of cytokines (IL-1 $\beta$, IL-2R $\alpha$, IL-2, IL-4, IL-5, IL-6, IL-7, IL-8, IL-9, IL-10, IL-12 (p70), IL-13, IL-15, IL-17), Eotaxin, basic fibroblast growth factor (FGFb), granulocyte colony-stimulating factor (G-CSF), granulocyte macrophage colony-stimulating factor (GM-CSF), interferon gamma (INF $\gamma$ ), interferon gamma-induced protein 10 (IP-10), mast cell proteinase-1 (MCP-1), macrophage inflammatory protein 1-alpha (MIP-1 $\alpha$ ), macrophage inflammatory protein 1-beta (MIP-1 $\beta$ ), platelet-derived growth factor with two B subunits (PDGF-1bb), chemokine RANTES, tumor necrosis factor beta (TNF- $\beta$ ) and vascular endothelial growth factor (VEGF) in blood serum were performed using the multiplex analyzer Bio-Plex200 System (BioRad, Hercules, CA, USA) and "Bio-Plex Pro ${ }^{\mathrm{TM}}$ Human Cytokine 27-plex Assay" kit (BioRad, Hercules, CA, USA) according to the manufacturer's recommendations. 
Table 2. Multiple reaction monitoring (MRM) quantification proteins list.

\begin{tabular}{|c|c|c|c|c|c|c|}
\hline $\mathbf{n} / \mathbf{n}$ & Protein & $\begin{array}{c}\text { UniProt } \\
\text { Accession } \\
\text { Number }\end{array}$ & $\begin{array}{l}\text { Target Peptide } \\
\text { Sequence }\end{array}$ & $\begin{array}{c}\text { MRM } \\
\text { Transition } \\
\text { Q1 }\end{array}$ & $\begin{array}{c}\text { MRM } \\
\text { Transition } \\
\text { Q3 }\end{array}$ & Product Ion \\
\hline 1 & $\begin{array}{l}\text { Immunoglobulin superfamily member } \\
22 \text { (IGSF22) }\end{array}$ & Q8N9C0 & EDSGLILLK & 494.3 & 743.5 & y7 \\
\hline 2 & $\begin{array}{l}\text { T-complex protein } 1 \text { subunit delta } \\
\text { (CCT4) }\end{array}$ & P50991 & LVIEEAER & 479.8 & 655.4 & b6 \\
\hline 3 & Cullin-5 (CUL5) & Q93034 & EAFQDDPR & 489.2 & 777.4 & y6 \\
\hline 4 & Apolipoprotein A-IV (APOA4) & P06727 & LAPLAEDVR & 492.3 & 589.3 & y5 \\
\hline 5 & Apolipoprotein E (APOE) & P02649 & LGPLVEQGR & 484.8 & 588.3 & y5 \\
\hline 6 & Apolipoprotein A-I (APOA1) & P02647 & QGLLPVLESFK & 615.9 & 819.5 & y7 \\
\hline 7 & $\begin{array}{l}\text { Coiled-coil domain-containing protein } \\
\qquad 43 \text { (CCDC43) }\end{array}$ & Q96MW1 & LEALGVDR & 436.7 & 446.2 & y4 \\
\hline 8 & $\begin{array}{l}\text { Coiled-coil domain-containing protein } \\
171 \text { (CCDC171) }\end{array}$ & Q6TFL3 & TLQEALEK & 466.3 & 830.5 & y7 \\
\hline 9 & $\begin{array}{c}\text { Putative endoplasmin-like protein } \\
\text { (HSP90B2) }\end{array}$ & Q58FF3 & FDDSEK & 370.7 & 478.2 & y4 \\
\hline 10 & Plasminogen (PLG) & P00747 & LSSPAVITDK & 515.8 & 769.4 & b8 \\
\hline 11 & Phospholipase B1 (PLB1) & Q6P1J6 & TETLDLR & 424.2 & 445.2 & b4 \\
\hline 12 & $\begin{array}{l}\text { LIM and cysteine-rich domains protein } 1 \\
\text { (LMCD1) }\end{array}$ & Q9NZU5 & YSTLTAR & 406.2 & 465.2 & b4 \\
\hline 13 & Alpha-1-antitrypsin (AAT) & P01009 & LSITGTYDLK & 555.8 & 797.4 & y7 \\
\hline 14 & Villin-1 (VIL1) & P09327 & AFEVPAR & 395.2 & 442.3 & y4 \\
\hline 15 & NF-kappa-B-repressing factor (NKRF) & O15226 & EIPPADIPK & 490.3 & 736.4 & b7 \\
\hline 16 & $\begin{array}{c}\text { Amyloid protein-binding protein } 2 \\
\text { (APPBP2) }\end{array}$ & Q92624 & VVVDVLR & 400.3 & 700.4 & y6 \\
\hline 17 & $\begin{array}{l}\text { Serine/threonine-protein phosphatase } \\
\text { with EF-hands } 2 \text { (PPEF2) }\end{array}$ & O14830 & SLPSSPLR & 428.7 & 472.3 & y4 \\
\hline 18 & Ras GTPase-activating protein 4 (CAPRI) & O43374 & DELDLQR & 444.7 & 531.3 & y4 \\
\hline 19 & $\begin{array}{c}\text { Cytoskeleton-associated protein 2-like } \\
\text { (CKAP2L) }\end{array}$ & Q8IYA6 & QFVGETQSR & 526.3 & 776.4 & y7 \\
\hline 20 & Protein kinase $\mathrm{C}$ epsilon type (PKCE) & Q02156 & QINQEEFK & 518.2 & 613.2 & b5 \\
\hline 21 & Antigen KI-67 & P46013 & EDSTADDSK & 484.1 & 504.1 & b5 \\
\hline 22 & Complement factor $\mathrm{H}(\mathrm{CFH})$ & P08603 & NGFYPATR & 463.2 & 607.3 & y5 \\
\hline 23 & Complement C4 (C4A, C4B) & $\begin{array}{l}\text { P0C0L4 } \\
\text { P0C0L5 }\end{array}$ & LTSLSDR & 396.2 & 577.3 & y5 \\
\hline 24 & Ficolin-3 (FCN3) & O75636 & VELEDFNGNR & 596.8 & 722.3 & y6 \\
\hline 25 & $\begin{array}{l}\text { C4B-binding protein alpha chain } \\
\text { (C4BPA) }\end{array}$ & P04003 & TWYPEVPK & 510.3 & 569.3 & y5 \\
\hline 26 & Complement C1R subcomponent (C1R) & P00736 & GGGALLGDR & 408.2 & 460.3 & y4 \\
\hline 27 & Complement C1S subcomponent (C1S) & P09871 & LLEVPEGR & 456.8 & 686.3 & y6 \\
\hline 28 & $\begin{array}{c}\text { Complement } C 1 \mathrm{q} \text { subcomponent } \\
\text { subunit } C(\mathrm{C} 1 \mathrm{Q})\end{array}$ & P02747 & FQSVFTVTR & 542.8 & 623.4 & y5 \\
\hline 29 & Complement C3 (C3) & P01024 & IWDVVEK & 444.7 & 474.3 & y4 \\
\hline 30 & Complement C5 (C5) & P01031 & GTVYNYR & 436.7 & 452.2 & y3 \\
\hline 31 & $\begin{array}{l}\text { Complement component } \mathrm{C} 8 \text { alpha chain } \\
\qquad(\mathrm{C} 8 \mathrm{~A})\end{array}$ & P07357 & STITYR & 370.7 & 552.3 & y4 \\
\hline 32 & $\begin{array}{l}\text { Complement component } \mathrm{C} 8 \text { beta chain } \\
\text { (C8B) }\end{array}$ & P07358 & EYESYSDFER & 662.8 & 672.3 & b5 \\
\hline 33 & $\begin{array}{c}\text { Complement component } \mathrm{C} 8 \text { gamma } \\
\text { chain }(\mathrm{C} 8 \mathrm{G})\end{array}$ & P07360 & QLYGDTGVLGR & 589.8 & 678.3 & b6 \\
\hline 34 & Complement C9 (C9) & P02748 & VVEESELAR & 516.3 & 833.4 & y7 \\
\hline 35 & Mannose-binding protein C (MBL2) & P11226 & NAAENGAIQNLIK & 678.4 & 869.4 & b9 \\
\hline 36 & $\begin{array}{l}\text { Mannan-binding lectin serine protease } 2 \\
\text { (MASP2) }\end{array}$ & O00187 & WPEPVFGR & 494.3 & 609.3 & b5 \\
\hline 37 & Galectin-3 (Gal-3) & P17931 & LDNNWGR & 437.7 & 671.3 & y6 \\
\hline 38 & Galectin-3-binding protein (M2BP) & Q08380 & VEIFYR & 413.7 & 727.4 & y5 \\
\hline
\end{tabular}

\subsection{Statistical Analysis}

Statistical analysis of the multiple reaction monitoring (MRM) data and ELISA data were performed in the R environment [21]. Statistically significant differences between groups of patients and healthy individuals were accepted as $p<0.05$, assessed by the Wilcoxon rank sum test with Benjamini-Hochberg adjustment for MRM data and $p<0.01$ for ELISA data. Correlations between the concentrations of serum proteins, cytokines, urea and creatinine were analyzed using the R Hmisc package (based on Spearman's rank correlation coefficient). 


\section{Results}

Two-dimensional fluorescence difference gel electrophoresis (2D-DIGE) is a convenient method to identify differences in protein profiles of the samples compared; however, it imposes a number of requirements on an analyte. In particular, successful separation and visualization of protein spots in gel depend upon concentrations of the proteins analyzed. The serum proteome has a dynamic range of more than ten orders of magnitude; thus, there is an excess of major proteins of albumin (more than $60 \%$ of the total amount of proteins), alpha-, beta- and gamma-globulin fractions (over 30\%), with the rest being less than $10 \%$ of the total number of serum proteins [4,22,23]. Prior to 2D gel-electrophoresis, samples were depleted with the use of a commercial "ProteoMiner" kit (Bio-Rad) in order to remove major proteins. As can be seen in Figure 1, removal of most of the major fraction facilitated better blood serum protein separation. Protein spots with different expression levels between two patients and two healthy subjects were cut off and identified; these data are presented in Supplementary Table S2. Some proteins were presented by several spots on 2D gel, probably being isoforms of the same protein.
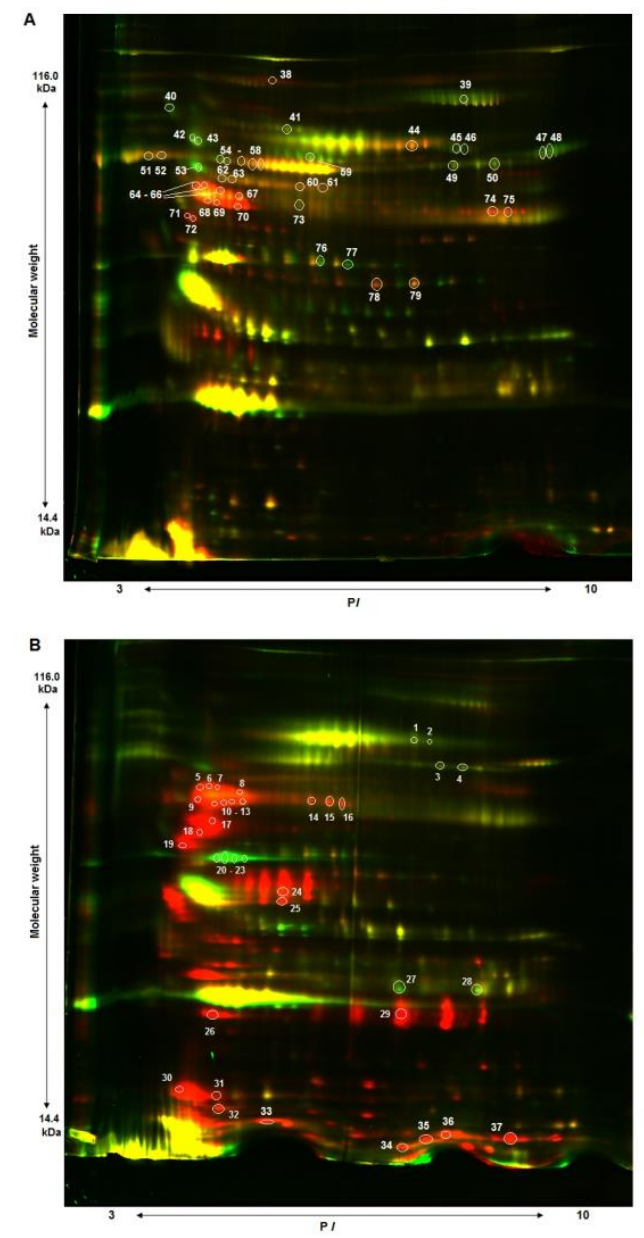

Figure 1. 2D-DIGE protein profiles of depleted serum of patients with chronic kidney disease (CKD; red fluorescent dye) and healthy individuals (green fluorescent dye). (A) serum of two women, 30 and $35 \mathrm{y}$. (B) serum of two men, 34 and $32 \mathrm{y}$. 
Fifty-six unique, differentially expressed proteins between CKD patients and healthy subjects were identified with MALDI mass spectrometry, and we surmised there might be potential diagnostic markers of early CKD stages among these proteins. To test this hypothesis, 20 proteins with differential expression were quantified in the serum of CKD patients $(n=26)$ and healthy volunteers $(n=10)$ using MRM (multiple reaction monitoring). At present, MRM is an advanced method of mass spectrometry and allows simultaneous quantitation of numerous protein concentrations by the signal intensity of daughter ions, being fragments of known parent peptides [24]. For this purpose, we analyzed amino acid sequences of chosen proteins and selected relevant peptides to quantify proteins of interest using Skyline software (Table 2).

Two apolipoproteins, APOA1 and APOA4, were included in the list of proteins selected for MRM, with APOE added as a component that plays an important role in lipid metabolism and is associated with impaired hemodialysis and renal transplant functioning. Moreover, 18 complement system proteins were added into the expanded list, as they were directly involved in inflammatory reactions (Table 2).

The quantification results for proteins with differential expression in 2D-DIGE and those associated with the complement system are shown in Figures 2 and 3.

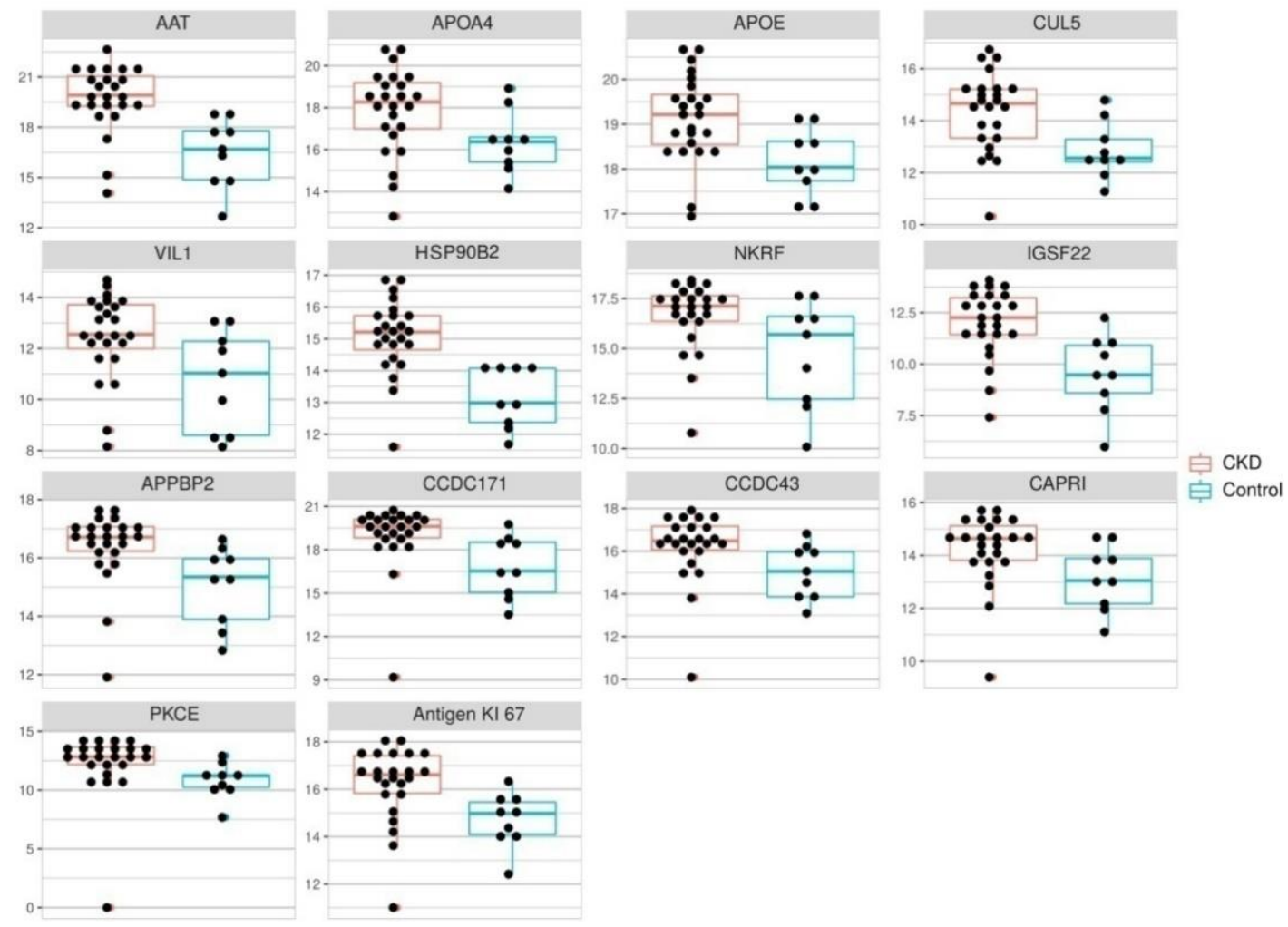

Figure 2. Dot plots of complement system components levels in the serum of healthy individuals ( $n=10$, yellow) and patients with CKD $(n=26$, blue). Levels are expressed as areas of MRM transition peaks. Wilcoxon rank sum test was performed in each case, $p$ value $<0.05$. 
In general, concentrations of 26 proteins enlisted in Table 2 were significantly different in patients with CKD and healthy subjects (Figures 2 and 3, Supplementary Tables S3 and S4). IGSF22, HSP90B2, AAT, C4BPA, C3, C1R and C9 concentrations increased more than four times in the group of CKD patients as compared to the control. Serum CFH, CUL5, PKCE, APOA4, APOE, CCDC171, CCDC43, VIL1, antigen KI-67, NKRF, APPBP2, CAPRI, C1QC, C1S, C4, C5, C8A, C8B and MBL2 concentrations were two to three times elevated in patients with $\mathrm{CKD}$. Concentrations of the remaining proteins such as CCT4, PLG, APOA1, LMCD1, CKAP2L, PLB1, PPEF2, Gal-3, MASP2, C6 and FCN3 were not significantly different between the group of CKD patients and healthy subjects. Only the concentration of C8G was significantly decreased (three-fold) in patients with CKD.

To assess the immune status serum concentrations of 27 cytokines, chemokines and growth factors such as IL-1 $\beta$, IL-2R $\alpha$, IL-2, IL-4, IL-5, IL-6, IL-7, IL-8, IL-9, IL-10, IL-12 (p70), IL-13, IL-15, IL-17, Eotaxin, FGFb, G-CSF, GM-CSF, INF $\gamma$, IP-10, MCP-1, MIP-1 $\alpha$, MIP-1 $\beta$, PDGF-1bb, RANTES, TNF- $\alpha$ and VEGF, they were quantified using Luminex xMAP technology (Figure 4). The analysis showed that serum concentrations of IL- 9 and MIP-1 $\beta$ were elevated $>500$ times; those of IL-1 $\beta$, IL-8, IL-12 (p70), IL-13, IL-15, IP-10, RANTES and VEGF increased >100 times; IL-6, GM-CSF, MIP-1 $\alpha$ and PDGF-1bb levels were elevated >50 times; IL-2, IL-4, IL-7, IL-10 and IL-17 were 20-40 times higher; and those of IL-5, Eotaxin, FGFb, G-CSF, MCP-1 and TNF- $\alpha$ increased 6-12 times in patients with CKD (n = 19) when compared to the control group $(n=10)$. The INF $\gamma$ concentration did not significantly differ between the groups. The blood serum concentration of soluble IL-2R $\alpha$ was reduced 1.5 times in patients versus the control group.

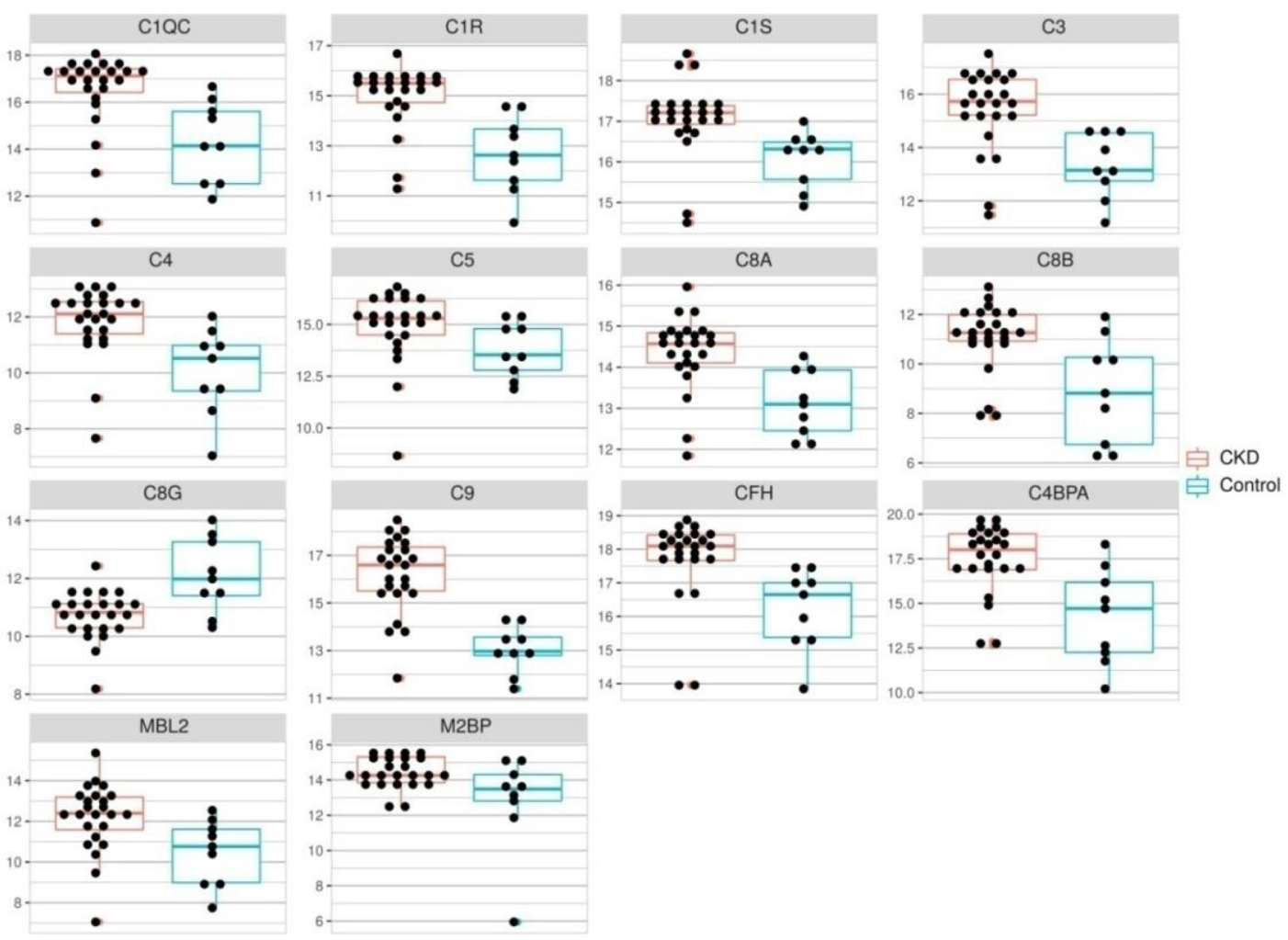

Figure 3. Dot plots of differently expressed protein levels in the serum of healthy individuals $(n=10$, yellow) and patients with CKD ( $n=26$, blue). Levels are expressed as areas of MRM transition peaks. Wilcoxon rank sum test was performed in each case, $p$ value $<0.05$.

As concentrations of most proteins and cytokines analyzed were significantly different in the group of CKD patients and healthy subjects, clustering of quantitative serum protein proteomic analysis results, cytokine multiplex analysis data and creatinine and urea biochemistry results were 
compiled (Figure 5, Supplementary Table S5). As can be seen from the heat map data, an increase of all analyzed cytokines, except for IL-2R $\alpha$ and INF $\gamma$, positively correlated with serum creatinine and urea concentrations $(\mathrm{R}>0.6, p$ value $<0.05)$. Serum AAT concentration demonstrated a moderate, positive correlation $(\mathrm{R}=0.44, p$ value $<0.05)$ with creatinine and some cytokines (IL-2, IL-6, IL-7, IL-9, MIP-1 $\alpha$, RANTES; R > 0.5, $p$ value < 0.05). HSP90B2 positively correlated with those of creatinine and urea and most of the measured cytokines (IL-2, IL-6, IL-7, IL-8, IL-9, IL-10, IL-13, IL-17, G-CSF, GM-CSF, MIP-1 $\alpha$, MIP-1 $\beta$, RANTES, TNF- $\alpha$ and VEGF; R > 0.5, $p$ value $<0.05)$. Serum APOE, IGSF22, CUL5, CCDC171, CAPRI, CCDC43, Antigen KI-67, PKCE and APPBP2 levels positively correlated only with those of some cytokines such as IL-2, IL-9, MIP-1a, TNF- $\alpha$ and/or IL-13, IL-17, RANTES $(\mathrm{R}>0.4, p$ value $<0.05)$. Serum APOA4, APOA1, VIL1 and NKRF concentrations had no correlations with creatinine, urea and cytokines.

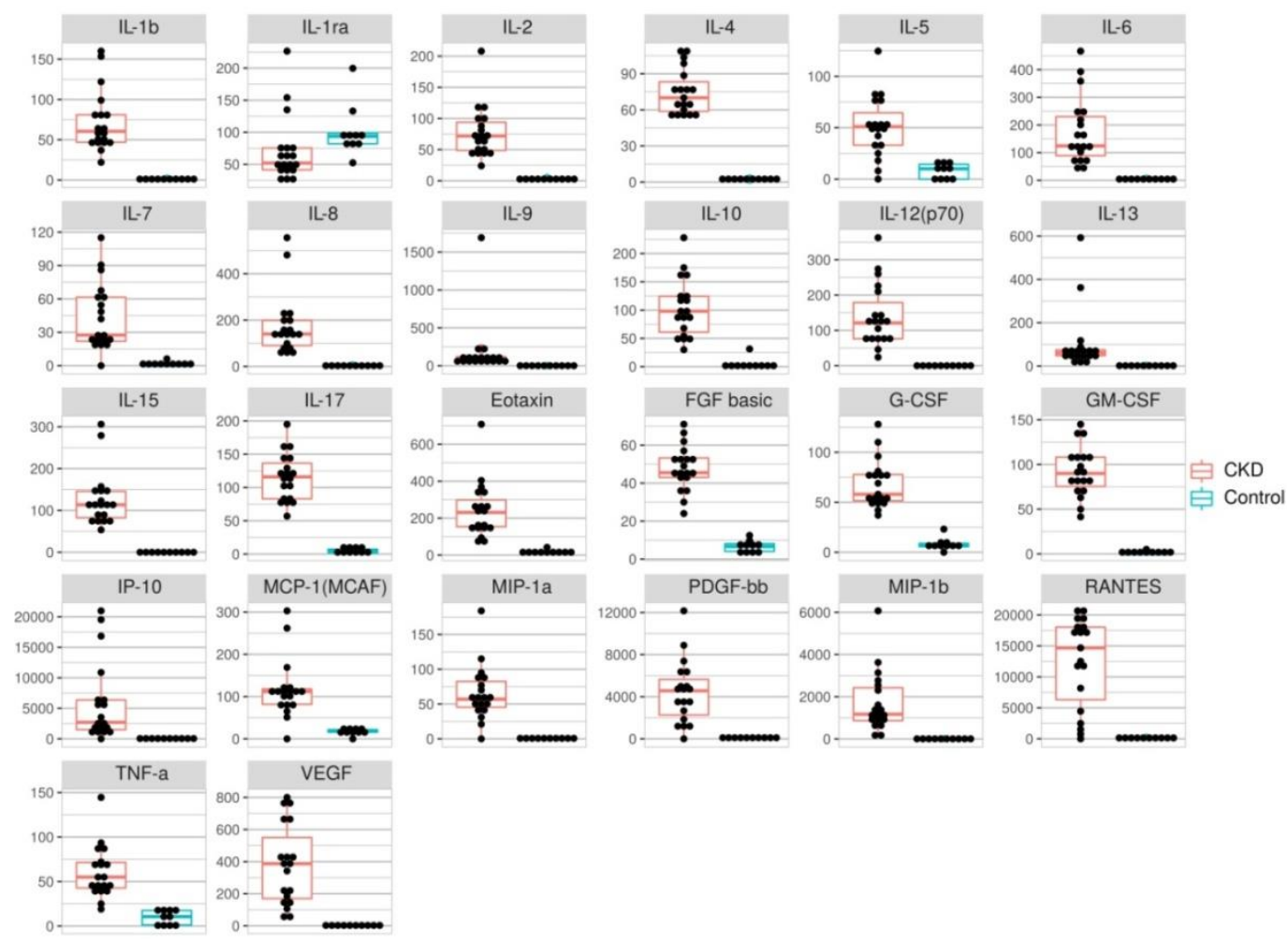

Figure 4. Dot plots of serum levels $(\mathrm{pg} / \mathrm{mL})$ of 26 cytokines for healthy people $(\mathrm{n}=10$, red) and patients with CKD ( $n=19$, blue). Wilcoxon rank sum test was performed in each case, $p$ value $<0.01$.

Complement system components such as CFH, C1S, C1R, C1QC, C3, C4, C8A and C9 had a positive correlation with serum urea and/or creatinine levels $(R>0.4, p$ value $<0.05)$, as well as with cytokines (IL-2, IL-7, IL-9, IL-17, MIP-1 $\alpha$, RANTES and TNF- $\alpha$; R > 0.45, $p$ value < 0.05). MBL2 levels mildly correlated with some cytokines (IL-2, IL-9, MIP-1a, RANTES; $\mathrm{R}<-0.45, p$ value $<0.05$ ). C8G had a negative correlation with creatinine $(\mathrm{R}=-0.63, p$ value $<0.05)$ and most cytokines (IL-2, IL-4, IL-5, IL-6, IL-7, IL-8, IL-10, IL12(p70), IL-13, IL-15, IL-17, G-CSF, Eotaxin, FGFb and MIP-1ß; R < $-0.45, p$ value $<0.05$ ). The remaining complement system proteins (i.e., C5, C6, Gal3, MASP2 and M2BP) showed no significant correlation with the well-established CKD markers and cytokines.

The raw MRM data and gel images were deposited at jPOST database [25] under the project numbed as JPST000578 and JPST000579. 


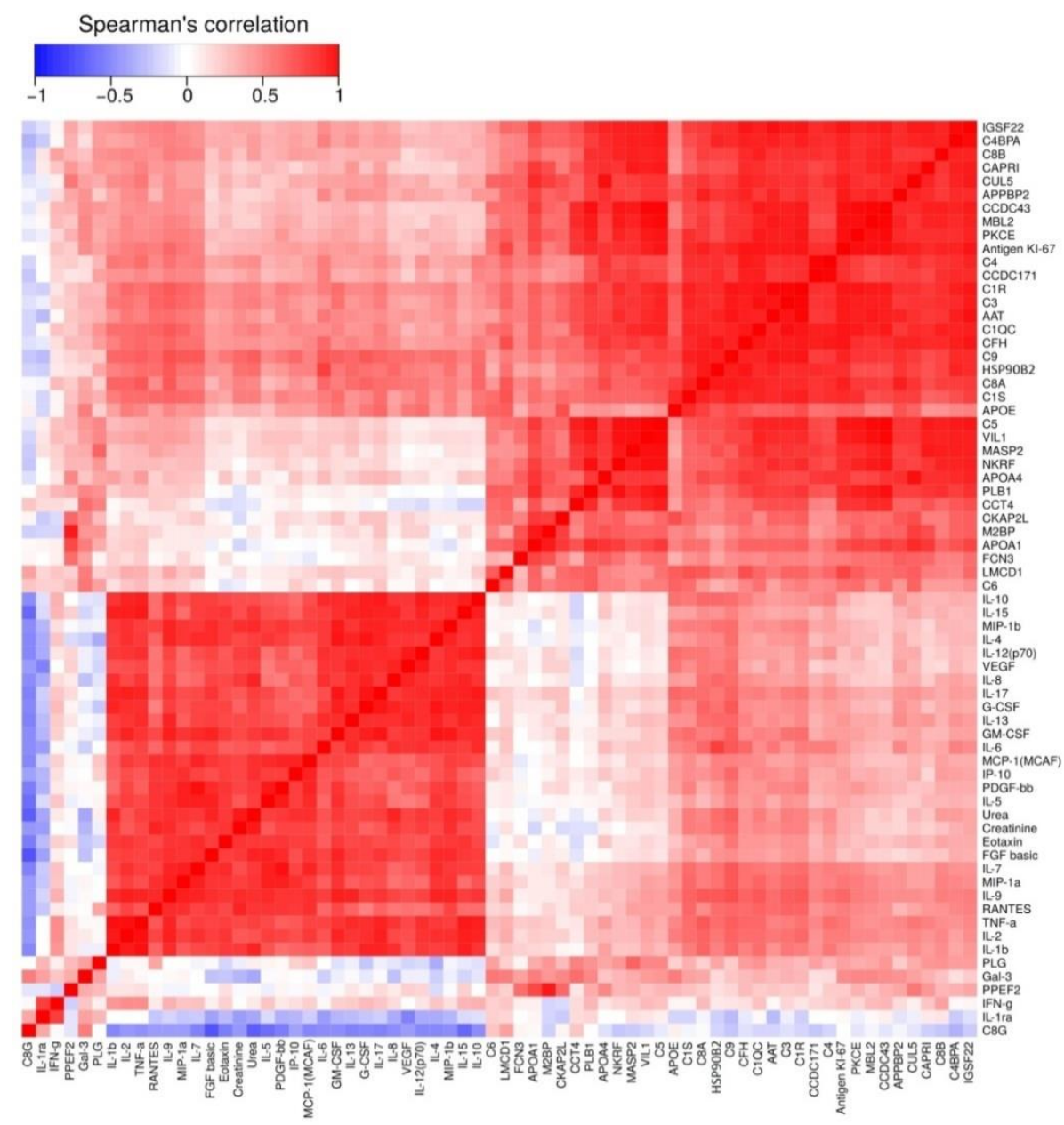

Figure 5. Heat map demonstrating correlations between urea, creatinine, cytokines and serum proteins. Hierarchical clustering of all analytes was performed by using the Euclidian distance method. The blue and red colors represent negative and positive Spearman's rank correlation coefficients between the two analytes, respectively.

\section{Discussion}

Modern diagnostics of CKD and monitoring of its course are based on the measurement of serum creatinine concentrations and subsequent calculation of the glomerular filtration rate [3,4]. The disadvantage of this method is its poor effectiveness in diagnosing early CKD. There are a number of studies where potential protein biomarkers of CKD were proposed and evaluated in the serum or plasma of patients $[7,8,11-14]$. Peptide biomarkers can also provide insight into CKD diagnosis and progression. In a recent study, 273 specific urinary peptides (CKD273 classifier) were identified as reliable predictors of CKD progression [26] and cardiovascular events in CKD [27]. In this study, we hypothesized that if some proteins showed significant quantitative changes in patient serum and correlated with well-established markers, then they would be potential biomarkers for CKD diagnosis. The first stage of our research involved the screening of serum proteins with differential expressions in patients with CKD and healthy individuals using the 2D-DIGE approach. Twenty-one proteins from the 2D dataset were selected as potential protein candidates for biomarkers of the disease (Table 2). AAT, APOA4 and VIL1 concentrations have previously been shown to increase in blood plasma as CKD progresses [28-31]. Our data confirm the increased blood serum concentrations of these proteins in patients; whereas only serum AAT values correlated with elevated levels of creatinine and cytokines. Our target proteomics results are compared with previously reported data from studies of different renal pathologies in Table 3. 
Table 3. Lists of elevated serum proteins from MRM data analysis compared to the previously reported results.

\begin{tabular}{|c|c|c|c|c|c|c|c|}
\hline $\mathbf{n} / \mathbf{n}$ & Protein & Fold Change & $\begin{array}{l}\text { SC between Protein } \\
\text { and Creatinine }\end{array}$ & $\begin{array}{c}\text { SC between Protein } \\
\text { and Urea }\end{array}$ & Reference & Study Population & Results \\
\hline \multirow{3}{*}{1} & \multirow{3}{*}{ APOA4 } & \multirow{3}{*}{$3.4 * \uparrow$} & \multirow{3}{*}{0.07} & \multirow{3}{*}{0.19} & [32] & $\begin{array}{l}345 \text { CKD patients with type } \\
2 \text { diabetes }\end{array}$ & Increased plasma level of APOA4 \\
\hline & & & & & [33] & 177 CKD patients & $\begin{array}{l}\text { Increased serum level of APOA4 were significant } \\
\text { predictors of disease progression }\end{array}$ \\
\hline & & & & & [34] & $\begin{array}{l}6220 \text { participants of general } \\
\text { population }\end{array}$ & $\begin{array}{l}\text { Increased serum level of APOA4 were significant } \\
\text { predictors of disease progression }\end{array}$ \\
\hline \multirow{5}{*}{2} & \multirow{5}{*}{$\mathrm{APOE}$} & \multirow{5}{*}{$2.1 * * \uparrow$} & \multirow{5}{*}{0.30} & \multirow{5}{*}{0.30} & [35] & 117 CKD patients & APOE was a negative predictor of eGFR reduction rate \\
\hline & & & & & [36] & 109 HD patients & APOE were significantly decreased \\
\hline & & & & & [8] & 90 CKD patients & $\begin{array}{l}\text { Elevated level of APOE in plasma of patients with CKD } \\
1-2 \text { stages }\end{array}$ \\
\hline & & & & & [37] & $301 \mathrm{HD}$ patients & $\begin{array}{l}\text { HD patients had a significantly lower prevalence of the } \\
\text { E4 allele and greater levels of APOE }\end{array}$ \\
\hline & & & & & [38] & 7 CKD patients & Increased plasma level of APOE \\
\hline \multirow{4}{*}{3} & \multirow{4}{*}{ APOA1 } & \multirow{4}{*}{$1.6 * \uparrow$} & \multirow{4}{*}{-0.16} & \multirow{4}{*}{-0.07} & [39] & $\begin{array}{l}17,315 \text { participants of the } \\
\text { general population }\end{array}$ & $\begin{array}{l}\text { Higher serum APOA1 was associated with lower } \\
\text { prevalence of CKD }\end{array}$ \\
\hline & & & & & [40] & $\begin{array}{l}50 \text { patients with CKD and } \\
198 \text { patients on HD therapy }\end{array}$ & $\begin{array}{l}\text { CKD was found to be associated with highly significant } \\
\text { reductions in plasma APOA1 }\end{array}$ \\
\hline & & & & & [8] & 90 CKD patients & $\begin{array}{l}\text { No differences between plasma APOA1 level of patients } \\
\text { with CKD 1-2 stages and healthy voluntaries }\end{array}$ \\
\hline & & & & & [11] & $\begin{array}{l}76 \text { patients who received } \\
\text { initial insertion of PD }\end{array}$ & $\begin{array}{l}\text { APOA1 showed enhanced levels in PD effluents of } \\
\text { patients with high transporter }\end{array}$ \\
\hline 4 & IGSF22 & $4.5^{* *} \uparrow$ & 0.34 & 0.35 & [41] & $\begin{array}{l}7 \text { patients with clear } \\
\text { cell carcinoma }\end{array}$ & $\begin{array}{l}\text { Found in a renal cell carcinoma sample; } \\
\text { somatic mutation }\end{array}$ \\
\hline 5 & HSP90B2 & $4.0^{* * \uparrow}$ & $0.55^{* *}$ & $0.56^{* *}$ & - & - & - \\
\hline \multirow{3}{*}{6} & \multirow{3}{*}{ AAT } & \multirow{3}{*}{$8.7^{* *} \uparrow$} & \multirow{3}{*}{$0.44^{*}$} & \multirow{3}{*}{0.41} & [12] & $\begin{array}{l}12 \text { non-diabetic } \\
\text { ESRD patients }\end{array}$ & $\begin{array}{l}\text { HD patients had altered plasma profiles of } \\
\text { AAT isoforms }\end{array}$ \\
\hline & & & & & [31] & $\begin{array}{l}63 \text { patients with primary } \\
\text { membranous nephropathy }\end{array}$ & Increased urinary level of AAT \\
\hline & & & & & [42] & 103 HD patients & $\begin{array}{l}\text { Higher serum AAT levels select the HD patients with } \\
\text { severe inflammation from those without }\end{array}$ \\
\hline
\end{tabular}


Table 3. Cont.

\begin{tabular}{|c|c|c|c|c|c|c|c|}
\hline $\mathbf{n} / \mathbf{n}$ & Protein & Fold Change & $\begin{array}{l}\text { SC between Protein } \\
\text { and Creatinine }\end{array}$ & $\begin{array}{l}\text { SC between Protein } \\
\text { and Urea }\end{array}$ & Reference & Study Population & Results \\
\hline \multirow[t]{2}{*}{7} & \multirow{2}{*}{ VIL1 } & \multirow{2}{*}{$2.6 * \uparrow$} & \multirow{2}{*}{0.08} & \multirow{2}{*}{0.18} & [43] & $\begin{array}{l}3 \text { patients with AKI after } \\
\text { liver transplantation }\end{array}$ & $\begin{array}{l}\text { VIL1 is released in plasma during AKI and shows } \\
\text { potential as an early marker for proximal tubular injury }\end{array}$ \\
\hline & & & & & [29] & 3 renal transplant recipients & VIL1 concentrations in the urine up to $20 \mathrm{mg} / \mathrm{I}$ \\
\hline 8 & $\begin{array}{l}\text { Antigen } \\
\text { KI-67 }\end{array}$ & $3.2 * \uparrow$ & 0.31 & 0.31 & [44] & $\begin{array}{l}351 \text { patients with clear cell } \\
\text { carcinoma }\end{array}$ & $\begin{array}{l}\text { Ki-67 are significant prognostic factors of clear cell } \\
\text { carcinoma }\end{array}$ \\
\hline 9 & $\mathrm{CFH}$ & $2.7 * \uparrow$ & $0.43^{*}$ & $0.43^{*}$ & [45] & 63 patients with $\mathrm{RD}$ & Urinary CFH levels were significantly higher in patients \\
\hline \multirow{2}{*}{10} & \multirow{2}{*}{$\mathrm{C} 4 \mathrm{~A}$} & \multirow{2}{*}{$2.8^{* * \uparrow}$} & \multirow{2}{*}{0.42} & \multirow{2}{*}{$0.45^{*}$} & [38] & 7 CKD patients & Increased plasma level of CA4 \\
\hline & & & & & [13] & 90 patients with CKD & Increased plasma level of CA4 \\
\hline 11 & C4BPA & $4.5^{* *} \uparrow$ & 0.3 & 0.38 & - & - & - \\
\hline 12 & $\mathrm{C} 1 \mathrm{R}$ & $4.1^{* *} \uparrow$ & $0.48^{*}$ & $0.49 *$ & [14] & 29 patients with CKD & Increased plasma level of $\mathrm{C} 1 \mathrm{R}$ \\
\hline 13 & $\mathrm{C} 1 \mathrm{~S}$ & $2.1^{* * \uparrow}$ & $0.51^{*}$ & $0.51 *$ & [14] & 29 patients with CKD & Increased plasma level of C1S \\
\hline 14 & C1QC & $3.7^{* * \uparrow}$ & $0.46^{*}$ & $0.50 *$ & [46] & 62 diabetic patients & No difference \\
\hline \multirow[t]{2}{*}{15} & \multirow[t]{2}{*}{ C3 } & \multirow[t]{2}{*}{$4.7^{* *} \uparrow$} & \multirow[t]{2}{*}{$0.48^{*}$} & \multirow[t]{2}{*}{$0.50 *$} & [11] & $\begin{array}{l}76 \text { patients who received } \\
\text { initial insertion of PD }\end{array}$ & $\begin{array}{c}\text { C3 showed enhanced expression in PD effluents of } \\
\text { patients with high transporter }\end{array}$ \\
\hline & & & & & [38] & 7 CKD patients & Increased plasma level of C3 \\
\hline 16 & $\mathrm{C} 5$ & $2.2 * \uparrow$ & 0.11 & 0.15 & [45] & 63 patients with $\mathrm{RD}$ & Increased urinary MAC (SC5b-9) \\
\hline 17 & $\mathrm{C} 8 \mathrm{~A}$ & $2.4^{* * \uparrow}$ & $0.48^{* *}$ & $0.47^{*}$ & [45] & 63 patients with $\mathrm{RD}$ & Increased urinary MAC (SC5b-9) \\
\hline 18 & $\mathrm{C} 8 \mathrm{~B}$ & $2.7^{* * \uparrow}$ & 0.25 & 0.38 & [45] & 63 patients with $\mathrm{RD}$ & Increased urinary MAC (SC5b-9) \\
\hline 19 & C8G & $3.1^{* *} \downarrow$ & -0.41 & $-0.63 *$ & [38] & 7 CKD patients & Decreased plasma level of C8G \\
\hline \multirow[b]{2}{*}{20} & \multirow[b]{2}{*}{ C9 } & \multirow[b]{2}{*}{$11^{* *} \uparrow$} & \multirow[b]{2}{*}{$0.58^{* *}$} & \multirow[b]{2}{*}{$0.62 * *$} & [45] & 63 patients with $\mathrm{RD}$ & Increased urinary MAC (SC5b-9) \\
\hline & & & & & [47] & $\begin{array}{c}53 \text { patients with } \\
\text { different nephropathy }\end{array}$ & $\begin{array}{l}\text { Urinary C9 was elevated in MCD, MN and FSGS } \\
\text { groups compared with in IgA nephropathy and } \\
\text { healthy controls }\end{array}$ \\
\hline 21 & MBL2 & $3.4^{* * \uparrow}$ & 0.18 & 0.18 & [46] & 62 diabetic patients & MBL was found to increase with the progression of DN \\
\hline 22 & CUL5 & $3.3^{* *} \uparrow$ & 0.23 & 0.29 & - & - & - \\
\hline 23 & PKCE & $3.2 * \uparrow$ & 0.27 & 0.28 & - & - & - \\
\hline 24 & CCDC43 & $2.2 * \uparrow$ & 0.18 & 0.22 & - & - & - \\
\hline 25 & CDC171 & $3.1^{* *} \uparrow$ & 0.33 & 0.38 & - & - & - \\
\hline 26 & CAPRI & $2.1 * \uparrow$ & 0.18 & 0.23 & - & - & - \\
\hline
\end{tabular}

$* p<0.05$, ** $p<0.005, \uparrow$ —increased in CKD patients, $\downarrow$ —decreased in CKD patients. Abbreviations: SC—Spearman's rank correlation coefficient, HD—hemodialysis, PD—peritoneal dialysis, ESRD—end-stage renal disease, AKI—acute kidney injury, RD—renal disease, MCD—minimal change disease, MN—membranous nephropathy, FSGS—focal segmental glomerulosclerosis, DN-diabetic nephropathy. 
AAT, which is supposed to have anti-inflammatory properties, belongs to the group of serine proteinases [27]. Exogenous AAT inhibited apoptosis and inflammation in renal reperfusion [28] and reduced the urine kidney injury molecule-1 (KIM-1) concentration [30]. Several studies have demonstrated increased blood plasma AAT concentrations in hypoxia [31] and acute myocardial infarction [48,49].

Based on the MRM results, APOE concentrations were significantly higher in the group of patients with CKD, whereas serum APOA1 levels showed no changes. However, in previously reported studies, plasma APOE and APOA1 levels differed for patients with and without CKD, apparently depending on the disease stage and therapy $[35,50,51]$. In particular, hemodialysis and pharmacotherapy might have an impact on the levels of these proteins.

High antigen KI-67 and CUL5 expression levels in tissues are associated with cancers [44,52-56]. We observed increased serum concentrations of these proteins in patients with CKD in this study. Furthermore, we saw increased levels of other intracellular proteins such as NKRF, CCDC171, CAPRI, CCDC43, APPBP2, IGSF22 and PKCE, which might be associated with renal tissue necrosis and, thus, with disease progression. The literature on these proteins in CKD is limited and/or contradictory. IGSF22 is known to be similar to cytoskeletal proteins in its structure, with a one-nucleotide substitution in the IGSF22 gene associated with the development of renal carcinoma [41]. The information on PKCE is controversial; protein kinase activation in proximal nephron cells leads to impaired functioning of the mitochondria, oxidative stress, energy deficiency and cell death [57]. At the same time, there is evidence that PKCE has protective functions against ischemic injury in other tissues, particularly in the myocardium and neurons [58-61]. NKRF is a transcriptional repressor of NF-kappa-B responsive genes [62]. Increased expression of NKRF transcription factor was shown to upregulate IL-1-induced secretion of IL-8 [63]. In our study, increased serum levels of IL-1 and IL-8 were also demonstrated, suggesting that NKRF could synergize with IL-1 to induce IL-8 expression. It should be noted that serum HSP90B2 concentration positively correlated with levels of creatinine, urea and a number of cytokines. However, the data on changes of serum HSP90B2 in various pathologies are presently lacking. We have evaluated key complement system proteins known to be important components of innate immunity and to play important roles in body defense, inflammation, tissue regeneration and other physiological processes. We found that serum C1S, C1QC and C4 concentrations increased two to three times, and that of C1R was elevated four times in patients with CKD, as compared to the control subjects. Increased levels of these proteins might indicate the activation of the complement system under the classic pathway. It is noteworthy that concentrations of lectin pathway activators such as FCN3, Gal-3 and MASP2 did not show any significant difference between the groups, although the MBL2 concentration was twice as high in patients with CKD. MBL2 has been previously shown to be capable of binding with apoptotic and necrotic cells, thereby promoting the activation of phagocytosis of dying cells [64].

Serum concentrations of complement system inhibitors factor $\mathrm{H}$ and C4BP were elevated two and four times, respectively, in CKD patients. We found significantly elevated concentrations (two times) of late lytic cascade proteins such as $\mathrm{C} 5, \mathrm{C} 8 \mathrm{~A}$ and $\mathrm{C} 8 \mathrm{~B}$, and both $\mathrm{C} 3$ and $\mathrm{C} 9$ were more than four times higher in CKD patients. These data are in consistent with previously reported results about higher plasma MAC (C5b-9) levels in patients with renal diseases [45,46].

It is remarkable that the serum concentration of the subunit $\mathrm{C} 8 \mathrm{G}$ did not elevate following the increase of $\mathrm{C} 8 \mathrm{~A}$ and $\mathrm{C} 8 \mathrm{~B}$ subunits constituting a single $\mathrm{C} 8$ protein. Unlike $\mathrm{C} 8 \mathrm{~A}$ and $\mathrm{C} 8 \mathrm{~B}$, the $\mathrm{C} 8 \mathrm{G}$ subunit is a member of the lipocalin family. As Lovelace et al. have previously reported [65], C8g is not involved in the formation of a membrane attack complex, but it only enhances its activity [65]. Perhaps, the subunit C8G has a regulator function as a complement system inhibitor. Furthermore, it has been suggested that decrease in serum C8G might be specific for other chronic diseases.

Increased blood serum levels of cytokines such as IL-4, IL-5, IL-6, IL-10 and IL-13, G-CSF, eotaxin and MIP- $1 \beta$ might indicate the activation of Th2 cells responsible for the development of humoral immune responses $[66,67]$. It should be noted that increased blood levels of cytokines involved in 
the activation of Th1 cells as well as IL-2, GM-CSF, TNF- $\alpha$, IL-12, RANTES, MIP-1 $\alpha$ and IL-18 were previously observed in patients with CKD $[68,69]$. Simultaneous activation of Th1 and Th2 cells was shown in various renal pathologies [69-71] and in a number of other diseases [72-74]. Moreover, significantly increased IL-9 might suggest ongoing differentiation of T-cells into a Th9 population [73].

\section{Conclusions}

Early diagnosis of renal dysfunction is essential to improve disease progress and survival of patients with CKD. In this research we quantified differentially expressed proteins and complement components using the MRM approach and measured serum concentrations of cytokines, chemokines and growth factors using the multiplex Luminex xMAP technology in patients with CKD and healthy subjects.

Our results correlate well with the data obtained by other researchers in that blood APOA4, AAT, VIL1, complement component and cytokine concentrations increased in patients with renal disorders [8,11-14,28,32-34,43,69-71]. Moreover, we found elevated serum concentrations of potential oncomarkers (CUL5, antigen KI-67) and other intracellular proteins (NKRF, CAPRI, IGSF22, APPBP2, CCD171 and CCD43) in patients with CKD. The reasons for this increase in blood serum and the role they play in renal tissue injury are not clear and require further investigations.

Patient serum levels of AAT, IGS22 and HSP90B2 had a greater than four-fold change. In addition, the data analysis showed a mild correlation between increased serum concentrations of AAT and HSP90B2 in patients with CKD and well-established markers of CKD such as creatinine and urea. Thus, we suggest that proteins AAT and HSP90B2 might be associated with kidney diseases and might be potential markers of CKD. Further investigations of these proteins as early biomarkers are needed to elucidate their clinical usefulness.

Supplementary Materials: The following are available online at http://www.mdpi.com/2218-273X/10/2/257/s1, Table S1: List of peptides for MRM analysis, Table S2: Proteins differentially expressed between CKD and control groups, Table S3: Average mean, standard error and standard deviation, Table S4: Significant differences, P-value $<0.05$, Table S5: Spearman's rank correlation.

Author Contributions: Conceptualization, Y.R. and S.K.; investigation Y.R., A.L. and R.K.; writing一original draft preparation, Y.R.; writing-review and editing, Y.R., S.K., A.R. and I.S.; formal analysis, A.L. and M.M.; resources, A.M. and M.H.; supervision, A.R. and I.S. All authors have read and agreed to the published version of the manuscript.

Funding: The work is performed according to the Russian Government Program of Competitive Growth of the Kazan Federal University and subsidy allocated to the Kazan Federal University for the state assignment in the sphere of scientific activities. The research was performed using the equipment of the Interdisciplinary Center for Shared Use of the Kazan Federal University supported by the Ministry of Education of Russia.

Conflicts of Interest: The authors declare no competing interests.

\section{References}

1. Jha, V.; Garcia-Garcia, G.; Iseki, K.; Li, Z.; Naicker, S.; Plattner, B.; Saran, R.; Wang, A.Y.; Yang, C.W. Chronic kidney disease: Global dimension and perspectives. Lancet 2013, 382, 260-272. [CrossRef]

2. Naghavi, M.; Abajobir, A.A.; Abbafati, C.; Abbas, K.M.; Abd-Allah, F.; Abera, S.F.; Aboyans, V.; Adetokunboh, O.; Afshin, A.; Agrawal, A.; et al. Global, regional, and national age-sex specific mortality for 264 causes of death, 1980-2016: A systematic analysis for the Global Burden of Disease Study 2016. Lancet 2017, 390, 1151-1210. [CrossRef]

3. Andrassy, K.M. Comments on 'KDIGO 2012 Clinical Practice Guideline for the Evaluation and Management of Chronic Kidney Disease'. Kidney Int. 2013, 84, 622-623. [CrossRef] [PubMed]

4. Kriz, W.; LeHir, M. Pathways to nephron loss starting from glomerular diseases-insights from animal models. Kidney Int. 2005, 67, 404-419. [CrossRef] [PubMed]

5. Gentile, G.; Remuzzi, G. Novel Biomarkers for Renal Diseases? None for the Moment (but One). J. Biomol. Screen. 2016, 21, 655-670. [CrossRef]

6. Lam, C.W. 2. Inflammation, Cytokines and Chemokines in Chronic Kidney Disease. EJIFCC 2009, 20, 12-20. 
7. Carrero, J.J.; Park, S.H.; Axelsson, J.; Lindholm, B.; Stenvinkel, P. Cytokines, atherogenesis, and hypercatabolism in chronic kidney disease: A dreadful triad. Semin. Dial. 2009, 22, 381-386. [CrossRef]

8. Luczak, M.; Formanowicz, D.; Marczak, Ł.; Suszyńska-Zajczyk, J.; Pawliczak, E.; Wanic-Kossowska, M.; Stobiecki, M. iTRAQ-based proteomic analysis of plasma reveals abnormalities in lipid metabolism proteins in chronic kidney disease-related atherosclerosis. Sci. Rep. 2016, 6, 32511. [CrossRef]

9. Fourdinier, O.; Schepers, E.; Metzinger-Le Meuth, V.; Glorieux, G.; Liabeuf, S.; Verbeke, F.; Vanholder, R.; Brigant, B.; Pletinck, A.; Diouf, M.; et al. Serum levels of miR-126 and miR-223 and outcomes in chronic kidney disease patients. Sci. Rep. 2019, 9, 4477. [CrossRef]

10. Fujii, R.; Yamada, H.; Yamazaki, M.; Munetsuna, E.; Ando, Y.; Ohashi, K.; Ishikawa, H.; Shimoda, H.; Sakata, K.; Ogawa, A.; et al. Circulating microRNAs (miR-126, miR-197, and miR-223) are associated with chronic kidney disease among elderly survivors of the Great East Japan Earthquake. BMC Nephrol. 2019, 20, 474. [CrossRef]

11. Wen, Q.; Zhang, L.; Mao, H.P.; Tang, X.Q.; Rong, R.; Fan, J.J.; Yu, X.Q. Proteomic analysis in peritoneal dialysis patients with different peritoneal transport characteristics. Biochem. Biophys. Res. Commun. 2013, 438, 473-478. [CrossRef] [PubMed]

12. Lin, Y.-P.; Yang, C.-Y.; Liao, C.-C.; Yu, W.-C.; Chi, C.-W.; Lin, C.-H. Plasma Protein Characteristics of Long-Term Hemodialysis Survivors. PLoS ONE 2012, 7, e40232. [CrossRef] [PubMed]

13. Luczak, M.; Formanowicz, D.; Marczak, Ł.; Pawliczak, E.; Wanic-Kossowska, M.; Figlerowicz, M.; Stobiecki, M. Deeper insight into chronic kidney diseaserelated atherosclerosis: Comparative proteomic studies of blood plasma using 2DE and mass spectrometry. J. Transl. Med. 2015, 13, 20. [CrossRef] [PubMed]

14. Glorieux, G.; Mullen, W.; Duranton, F.; Filip, S.; Gayrard, N.; Husi, H.; Schepers, E.; Neirynck, N.; Schanstra, J.P.; Jankowski, J.; et al. New insights in molecular mechanisms involved in chronic kidney disease using high-resolution plasma proteome analysis. Nephrol. Dial. Transplant. 2015, 30, 1842-1852. [CrossRef]

15. Unlu, M.; Morgan, M.E.; Minden, J.S. Difference gel electrophoresis: A single gel method for detecting changes in protein extracts. Electrophoresis 1997, 18, 2071-2077. [CrossRef]

16. Tannu, N.S.; Hemby, S.E. Two-dimensional fluorescence difference gel electrophoresis for comparative proteomics profiling. Nat. Protoc. 2006, 1, 1732-1742. [CrossRef]

17. Wray, W.; Boulikas, T.; Wray, V.P.; Hancock, R. Silver staining of proteins in polyacrylamide gels. Anal. Biochem. 1981, 118, 197-203. [CrossRef]

18. Gharahdaghi, F.; Weinberg, C.R.; Meagher, D.A.; Imai, B.S.; Mische, S.M. Mass spectrometric identification of proteins from silver-stained polyacrylamide gel: A method for the removal of silver ions to enhance sensitivity. Electrophoresis 1999, 20, 601-605. [CrossRef]

19. Software, M.L. Skyline Targeted Mass Spec Environment. Available online: https://skyline.ms/project/home/ software/Skyline/begin.view (accessed on 6 February 2020).

20. MacLean, B.; Tomazela, D.M.; Shulman, N.; Chambers, M.; Finney, G.L.; Frewen, B.; Kern, R.; Tabb, D.L.; Liebler, D.C.; MacCoss, M.J. Skyline: An open source document editor for creating and analyzing targeted proteomics experiments. Bioinformatics 2010, 26, 966-968. [CrossRef]

21. R-project. The R Project for Statistical Computing. Available online: https://www.r-project.org/ (accessed on 6 February 2020).

22. Ihara, H.; Toya, N.; Kakinoki, T.; Tani, A.; Aoki, Y.; Hashizume, N.; Inada, Y.; Nanba, S.; Urayama, T.; Yoshida, M. Reference ranges for serum protein fractions as determined by capillary zone electrophoresis. Jpn. J. Electroph. 2001, 45, 69-74. [CrossRef]

23. Larsson, A.; Hansson, L.O. Plasma protein fractions in healthy blood donors quantitated by an automated multicapillary electrophoresis system. J. Chromatogr. Sci. 2006, 44, 479-483. [CrossRef]

24. Domanski, D.; Percy, A.J.; Yang, J.; Chambers, A.G.; Hill, J.S.; Freue, G.V.; Borchers, C.H. MRM-based multiplexed quantitation of 67 putative cardiovascular disease biomarkers in human plasma. Proteomics 2012, 12, 1222-1243. [CrossRef]

25. Okuda, S.; Watanabe, Y.; Moriya, Y.; Kawano, S.; Yamamoto, T.; Matsumoto, M.; Takami, T.; Kobayashi, D.; Araki, N.; Yoshizawa, A.C.; et al. jPOSTrepo: An international standard data repository for proteomes. Nucleic Acids Res. 2017, 45, D1107-D1111. [CrossRef]

26. Critselis, E.; Lambers Heerspink, H. Utility of the CKD273 peptide classifier in predicting chronic kidney disease progression. Nephrol. Dial. Transplant. 2016, 31, 249-254. [CrossRef] 
27. Verbeke, F.; Siwy, J.; Van Biesen, W.; Mischak, H.; Pletinck, A.; Schepers, E.; Neirynck, N.; Magalhães, P.; Pejchinovski, M.; Pontillo, C. The urinary proteomics classifier chronic kidney disease 273 predicts cardiovascular outcome in patients with chronic kidney disease. Nephrol. Dial. Transplant. 2019, gfz242, 18. [CrossRef] [PubMed]

28. Kronenberg, F.; Kuen, E.; Ritz, E.; Konig, P.; Kraatz, G.; Lhotta, K.; Mann, J.F.; Muller, G.A.; Neyer, U.; Riegel, W.; et al. Apolipoprotein A-IV serum concentrations are elevated in patients with mild and moderate renal failure. J. Am. Soc. Nephrol. 2002, 13, 461-469.

29. Zimmerhackl, L.B.; Leuk, B.; Hoschutzky, H. The cytoskeletal protein villin as a parameter for early detection of tubular damage in the human kidney. J. Chromatogr. 1991, 587, 81-84. [CrossRef]

30. Salih, M.; Demmers, J.A.; Bezstarosti, K.; Leonhard, W.N.; Losekoot, M.; van Kooten, C.; Gansevoort, R.T.; Peters, D.J.; Zietse, R.; Hoorn, E.J. Proteomics of Urinary Vesicles Links Plakins and Complement to Polycystic Kidney Disease. J. Am. Soc. Nephrol. 2016, 27, 3079-3092. [CrossRef]

31. Pang, L.; Li, Q.; Li, Y.; Liu, Y.; Duan, N.; Li, H. Urine proteomics of primary membranous nephropathy using nanoscale liquid chromatography tandem mass spectrometry analysis. Clin. Proteomics 2018, 15, 5. [CrossRef]

32. Peters, K.E.; Davis, W.A.; Ito, J.; Winfield, K.; Stoll, T.; Bringans, S.D.; Lipscombe, R.J.; Davis, T.M.E. Identification of Novel Circulating Biomarkers Predicting Rapid Decline in Renal Function in Type 2 Diabetes: The Fremantle Diabetes Study Phase II. Diabetes Care 2017, 40, 1548-1555. [CrossRef]

33. Boes, E.; Fliser, D.; Ritz, E.; König, P.; Lhotta, K.; Mann, J.F.; Müller, G.A.; Neyer, U.; Riegel, W.; Riegler, P.; et al. Apolipoprotein A-IV Predicts Progression of Chronic Kidney Disease: The Mild to Moderate Kidney Disease Study. Am. Soc. Nephrol. 2016, 17, 528-536. [CrossRef]

34. Stangl, S.; Kollerits, B.; Lamina, C.; Meisinger, C.; Huth, C.; Stöckl, A.; Dähnhardt, D.; Böger, C.A.; Krämer, B.K.; Peters, A.; et al. Association between apolipoprotein A-IV concentrations and chronic kidney disease in two large population-based cohorts: Results from the KORA studies. J. Intern. Med. 2015, 278, 410-423. [CrossRef]

35. Smajic, J.; Hasic, S.; Rasic, S. High-density lipoprotein cholesterol, apolipoprotein E and atherogenic index of plasma are associated with risk of chronic kidney disease. Med. Glas. (Zenica) 2018, 15, 115-121. [CrossRef]

36. Lahrach, H.; Ghalim, N.; Taki, H.; Kettani, A.; Er-Rachdi, L.; Ramdani, B.; Saile, R. Serum paraoxonase activity, high-sensitivity $\mathrm{C}$-reactive protein, and lipoprotein disturbances in end-stage renal disease patients on long-term hemodialysis. J. Clin. Lipidol. 2008, 2, 43-50. [CrossRef]

37. Liberopoulos, E.N.; Miltiadous, G.A.; Cariolou, M.; Tselepis, A.D.; Siamopoulos, K.C.; Elisaf, M.S. The influence of serum apolipoprotein E concentration and polymorphism on serum lipid parameters in hemodialysis patients. Am. J. Kidney Dis. 2004, 44, 300-308. [CrossRef]

38. Naseeb, U.; Shafqat, J.; Jägerbrink, T.; Zarina, S.; Alvestrand, A.; Jörnvall, H.; Axelsson, J. Proteome Patterns in Uremic Plasma. Blood Purif. 2008, 26, 561-568. [CrossRef]

39. Goek, O.N.; Kottgen, A.; Hoogeveen, R.C.; Ballantyne, C.M.; Coresh, J.; Astor, B.C. Association of apolipoprotein A1 and B with kidney function and chronic kidney disease in two multiethnic population samples. Nephrol. Dial. Transplant. 2012, 27, 2839-2847. [CrossRef]

40. Calabresi, L.; Simonelli, S.; Conca, P.; Busnach, G.; Cabibbe, M.; Gesualdo, L.; Gigante, M.; Penco, S.; Veglia, F.; Franceschini, G. Acquired lecithin:cholesterol acyltransferase deficiency as a major factor in lowering plasma HDL levels in chronic kidney disease. J. Intern. Med. 2015, 277, 552-561. [CrossRef]

41. Varela, I.; Tarpey, P.; Raine, K.; Huang, D.; Ong, C.K.; Stephens, P.; Davies, H.; Jones, D.; Lin, M.-L.; Teague, J.; et al. Exome sequencing identifies frequent mutation of the SWI/SNF complex gene PBRM1 in renal carcinoma. Nature 2011, 469, 539-542. [CrossRef]

42. Borawski, J.; Naumnik, B.; Myśliwiec, M. Serum alpha1-antitrypsin but not complement C3 and C4 predicts chronic inflammation in hemodialysis patients. Ren. Fail. 2003, 25, 589-593. [CrossRef]

43. Decuypere, J.P.; Ceulemans, L.J.; Wylin, T.; Martinet, W.; Monbaliu, D.; Pirenne, J.; Jochmans, I. Plasmatic Villin 1 Is a Novel In Vivo Marker of Proximal Tubular Cell Injury During Renal Ischemia-Reperfusion. Transplantation 2017, 101, e330-e336. [CrossRef]

44. Kim, S.H.; Park, W.S.; Park, E.Y.; Park, B.; Joo, J.; Joung, J.Y.; Seo, H.K.; Lee, K.H.; Chung, J. The prognostic value of BAP1, PBRM1, pS6, PTEN, TGase2, PD-L1, CA9, PSMA, and Ki-67 tissue markers in localized renal cell carcinoma: A retrospective study of tissue microarrays using immunohistochemistry. PLoS ONE 2017, 12, e0179610. [CrossRef] 
45. Nagamachi, S.; Ohsawa, I.; Suzuki, H.; Sato, N.; Inoshita, H.; Hisada, A.; Honda, D.; Shimamoto, M.; Shimizu, Y.; Horikoshi, S.; et al. Properdin has an ascendancy over factor $\mathrm{H}$ regulation in complement-mediated renal tubular damage. BMC Nephrol. 2014, 15, 82. [CrossRef]

46. Zheng, J.M.; Ren, X.G.; Jiang, Z.H.; Chen, D.J.; Zhao, W.J.; Li, L.J. Lectin-induced renal local complement activation is involved in tubular interstitial injury in diabetic nephropathy. Clin. Chim. Acta 2018, 482, 65-73. [CrossRef]

47. Choi, Y.W.; Kim, Y.G.; Song, M.; Moon, J.-Y.; Jeong, K.-H.; Lee, T.-W.; Ihm, C.-G.; Park, K.-S.; Lee, S.-H. Potential urine proteomics biomarkers for primary nephrotic syndrome. Clin. Proteom. 2017, 14, 18. [CrossRef]

48. Wenger, R.H.; Rolfs, A.; Marti, H.H.; Bauer, C.; Gassmann, M. Hypoxia, a novel inducer of acute phase gene expression in a human hepatoma cell line. J. Biol. Chem. 1995, 270, 27865-27870. [CrossRef]

49. Brunetti, N.D.; Correale, M.; Pellegrino, P.L.; Cuculo, A.; Biase, M.D. Acute phase proteins in patients with acute coronary syndrome: Correlations with diagnosis, clinical features, and angiographic findings. Eur. J. Intern. Med. 2007, 18, 109-117. [CrossRef]

50. Gilutz, H.; Siegel, Y.; Paran, E.; Cristal, N.; Quastel, M.R. Alpha 1-antitrypsin in acute myocardial infarction. Br. Heart J. 1983, 49, 26-29. [CrossRef]

51. Borges, D.L.; Lemes, H.P.; de Castro Ferreira, V.; Filho, S.R.F. High-sensitivity C-reactive protein, apolipoproteins, and residual diuresis in chronic kidney disease patients undergoing hemodialysis. Clin. Exp. Nephrol. 2016, 20, 943-950. [CrossRef]

52. Rasmy, A.; Abozeed, W.; Elsamany, S.; Baiomy, M.E.; Nashwa, A.; Amrallah, A.; Hasaan, E.; Alzahrani, A.; Faris, M.; Alsaleh, K.; et al. Correlation of Preoperative Ki67 and Serum CA15.3 Levels with Outcome in Early Breast Cancers a Multi Institutional Study. Asian Pac. J. Cancer Prev. 2016, 17, 3595-3600.

53. Chauhan, R.; Lahiri, N. Tissue- and Serum-Associated Biomarkers of Hepatocellular Carcinoma. Biomark. Cancer 2016, 8, 37-55. [CrossRef]

54. Okumura, F.; Joo-Okumura, A.; Nakatsukasa, K.; Kamura, T. The role of cullin 5-containing ubiquitin ligases. Cell Div. 2016, 11, 1. [CrossRef]

55. Devor, E.J.; Schickling, B.M.; Reyes, H.D.; Warrier, A.; Lindsay, B.; Goodheart, M.J.; Santillan, D.A.; Leslie, K.K. Cullin-5, a ubiquitin ligase scaffold protein, is significantly underexpressed in endometrial adenocarcinomas and is a target of miR-182. Oncol. Rep. 2016, 35, 2461-2465. [CrossRef]

56. Chen, P.; Yao, G.D. The role of cullin proteins in gastric cancer. Tumour Biol. 2016, 37, 29-37. [CrossRef]

57. Nowak, G.; Takacsova-Bakajsova, D.; Megyesi, J. Deletion of protein kinase C-epsilon attenuates mitochondrial dysfunction and ameliorates ischemic renal injury. Am. J. Physiol. Renal Physiol. 2017, 312, F109-F120. [CrossRef]

58. Gray, M.O.; Karliner, J.S.; Mochly-Rosen, D. A selective epsilon-protein kinase C antagonist inhibits protection of cardiac myocytes from hypoxia-induced cell death. J. Biol. Chem. 1997, 272, 30945-30951. [CrossRef]

59. Garlid, K.D.; Costa, A.D.; Quinlan, C.L.; Pierre, S.V.; Dos Santos, P. Cardioprotective signaling to mitochondria. J. Mol. Cell. Cardiol. 2009, 46, 858-866. [CrossRef]

60. Della-Morte, D.; Raval, A.P.; Dave, K.R.; Lin, H.W.; Perez-Pinzon, M.A. Post-ischemic activation of protein kinase $\mathrm{C}$ epsilon protects the hippocampus from cerebral ischemic injury via alterations in cerebral blood flow. Neurosci. Lett. 2011, 487, 158-162. [CrossRef]

61. Morris-Blanco, K.C.; Dave, K.R.; Saul, I.; Koronowski, K.B.; Stradecki, H.M.; Perez-Pinzon, M.A. Protein Kinase C Epsilon Promotes Cerebral Ischemic Tolerance Via Modulation of Mitochondrial Sirt5. Sci. Rep. 2016, 6, 29790. [CrossRef]

62. Nourbakhsh, M.; Hoffmann, K.; Hauser, H. Interferon-b promoters contain a DNA element that acts as a position-independent silencer on the NF-kappaB site. EMBO J. 1993, 12, 451-459. [CrossRef]

63. Nourbakhsh, M.; Kalble, S.; Dorrie, A.; Hauser, H.; Resch, K.; Kracht, M. The NF-kappa b repressing factor is involved in basal repression and interleukin (IL)-1-induced activation of IL-8 transcription by binding to a conserved NF-kappa b-flanking sequence element. J. Biol. Chem. 2001, 276, 4501-4508. [CrossRef]

64. Nauta, A.J.; Raaschou-Jensen, N.; Roos, A.; Daha, M.R.; Madsen, H.O.; Borrias-Essers, M.C.; Ryder, L.P.; Koch, C.; Garred, P. Mannose-binding lectin engagement with late apoptotic and necrotic cells. Eur. J. Immunol. 2003, 33, 2853-2863. [CrossRef]

65. Lovelace, L.L.; Cooper, C.L.; Sodetz, J.M.; Lebioda, L. Structure of human C8 protein provides mechanistic insight into membrane pore formation by complement. J. Biol. Chem. 2011, 286, 17585-17592. [CrossRef] 
66. Garlisi, C.G.; Falcone, A.; Kung, T.T.; Stelts, D.; Pennline, K.J.; Beavis, A.J.; Smith, S.R.; Egan, R.W.; Umland, S.P. T cells are necessary for Th2 cytokine production and eosinophil accumulation in airways of antigen-challenged allergic mice. Clin. Immunol. Immunopathol. 1995, 75, 75-83. [CrossRef]

67. Mosmann, T.R.; Coffman, R.L. TH1 and TH2 cells: Different patterns of lymphokine secretion lead to different functional properties. Annu. Rev. Immunol. 1989, 7, 145-173. [CrossRef]

68. Schrum, S.; Probst, P.; Fleischer, B.; Zipfel, P.F. Synthesis of the CC-chemokines MIP-1alpha, MIP-1beta, and RANTES is associated with a type 1 immune response. J. Immunol. 1996, 157, 3598-3604.

69. Romanova, Y.D.; Markelova, M.I.; Laikov, A.V.; Fakhrutdinova, L.I.; Hasanova, M.I.; Malanin, S.Y.; Chernov, V.M.; Salafutdinov, I.I.; Khaiboullina, S.F. Cytokine Levels in the Serum of Patients with Chronic Kidney Insufficiency Before and After Hemodialysis. BioNanoScience 2017, 7, 415-418. [CrossRef]

70. Stangou, M.; Spartalis, M.; Daikidou, D.V.; Kouloukourgiotou, T.; Sampani, E.; Lambropoulou, I.T.; Pantzaki, A.; Papagianni, A.; Efstratiadis, G. Impact of Tauh1 and Tauh2 cytokines in the progression of idiopathic nephrotic syndrome due to focal segmental glomerulosclerosis and minimal change disease. J. Nephropathol. 2017, 6, 187-195. [CrossRef]

71. Rios, D.R.A.; Pinheiro, M.B.; de Oliveira Junior, W.V.; Braga Gomes, K.; Carvalho, A.T.; Martins-Filho, O.A.; Simoes, E.S.A.C.; Dusse, L.M.S. Cytokine Signature in End-Stage Renal Disease Patients on Hemodialysis. Dis. Markers 2017, 2017, 9678391. [CrossRef]

72. Bleotu, C.; Chifiriuc, M.C.; Grigore, R.; Grancea, C.; Popescu, C.R.; Anton, G.; Cernescu, C. Investigation of Th1/Th2 cytokine profiles in patients with laryngo-pharyngeal, HPV-positive cancers. Eur. Arch. Otorhinolaryngol. 2013, 270, 711-718. [CrossRef]

73. Bestetti, R.B.; Dellalibera-Joviliano, R.; Lopes, G.S.; Faria-Jr, M.; Furlan-Daniel, R.; Lopes, K.C.; Batista, D.R. Determination of the Th1, Th2, Th17, and Treg cytokine profile in patients with chronic Chagas heart disease and systemic arterial hypertension. Heart Vessels 2019, 34, 123-133. [CrossRef]

74. Khan, R.; Gupta, S.; Sharma, A. Circulatory levels of T-cell cytokines (interleukin [IL]-2, IL-4, IL-17, and transforming growth factor-beta) in patients with vitiligo. J. Am. Acad. Dermatol. 2012, 66, 510-511. [CrossRef]

(C) 2020 by the authors. Licensee MDPI, Basel, Switzerland. This article is an open access article distributed under the terms and conditions of the Creative Commons Attribution (CC BY) license (http://creativecommons.org/licenses/by/4.0/). 